\title{
Novel Helicobacter pylori $\propto 1,2-$ fucosyltransferase, a key enzyme in the synthesis of Lewis antigens
}

\author{
Ge Wang, ${ }^{1}$ Peter G. Boulton, ${ }^{1}$ Nora W. C. Chan, ${ }^{2}$ Monica M. Palcic ${ }^{2}$ \\ and Diane E. Taylor ${ }^{1}$
}

Author for correspondence: Diane E. Taylor. Tel: +1 780492 4777. Fax: +1 7804927521. e-mail: diane.taylor@ualberta.ca

Departments of Medical Microbiology and Immunology ${ }^{1}$ and Chemistry22, University of Alberta, Edmonton, $\mathrm{AB}$, Canada T6G 2H7

\begin{abstract}
Helicobacter pylori lipopolysaccharides (LPS) contain complex carbohydrates known as Lewis antigens which may contribute to the pathogenesis and adaptation of the bacterium. Involved in the biosynthesis of Lewis antigens is an $\alpha 1,2$-fucosyltransferase (FucT) that adds fucose to the terminal $\beta$ Gal unit of the 0-chain of LPS. Recently, the H. pylori (Hp) $\propto 1,2$-FucT-encoding gene (fucT2) was cloned and analysed in detail. However, due to the low level of expression and instability of the protein, its enzymic activity was not demonstrated. In this study, the Hp fucT2 gene was successfully overexpressed in Escherichia coli. Sufficient amounts of the protein were obtained which revealed $\alpha 1,2$ fucosyltransferase activity to be associated with the protein. A series of substrates were chosen to examine the acceptor specificity of Hp $\propto 1,2-\mathrm{FucT}$, and the enzyme reaction products were identified by capillary electrophoresis. In contrast to the normal mammalian $\alpha 1,2-$ FucT (H or Se enzyme), Hp $\alpha 1,2$-FucT prefers to use Lewis $X[\beta$ Gal1-4( $\alpha$ Fuc1-3) $\beta$ GIcNAc] rather than LacNAc [ $\beta$ Gal14/GICNAc] as a substrate, suggesting that $H$. pylori uses a novel pathway (via Lewis $X$ ) to synthesize Lewis $Y$. Hp $\alpha 1,2$-FucT also acts on type 1 acceptor [ $\beta$ Gal1-3/GIcNAc] and Lewis a [ $\beta$ Gal1-3( $\alpha$ Fuc1-4) $\beta$ GIcNAc], which provides $H$. pylori with the potential to synthesize $H$ type 1 and Lewis $b$ epitopes. The ability to transfer fucose to a monofucosylated substrate (Lewis $X$ or Lewis a) makes Hp $\propto 1,2$-FucT distinct from normal mammalian $\propto 1,2$-FucT.
\end{abstract}

Keywords: Helicobacter pylori, $\alpha 1,2$-fucosyltransferase, Lewis antigens

\section{INTRODUCTION}

Helicobacter pylori lipopolysaccharide (LPS), like the LPS present in the outer membranes of other Gramnegative bacteria, is composed of lipid A, an oligosaccharide core and the antigenic O-polysaccharide chain. Most strains of $H$. pylori express type 2 glycoconjugate antigens Lewis $\mathrm{X}\left(\mathrm{Le}^{\mathrm{X}}\right)$ and Lewis $\mathrm{Y}\left(\mathrm{Le}^{\mathrm{Y}}\right)$ in their LPS O-chain (Aspinall \& Monteiro, 1996; Aspinall et al., 1996; Sherburne \& Taylor, 1995; Wirth et al., 1996). Recent studies have also indicated the presence of type 1 epitopes in a small number of $H$. pylori isolates, and the LPS from a single $H$. pylori strain may carry O-

Abbreviations: FucT, fucosyltransferase; Hp, H. pylori; LacNAc, $\mathrm{N}$-acetyllactosamine; Le ${ }^{a}$, Lewis a; Le ${ }^{b}$, Lewis b; Le ${ }^{\mathrm{X}}$, Lewis $X$; Le ${ }^{Y}$, Lewis $Y$; TMR, tetramethylrhodamine. chains with type 1 and type 2 Lewis antigens simultaneously (Monteiro et al., 1998; Taylor et al., 1998; Wirth et al., 1997). The structures of these Lewis antigens in $\mathrm{H}$. pylori mimic those of the glycomolecules present on human gastric epithelial cell surfaces, although a direct correlation between Lewis expression by H. pylori and by the host cells is still uncertain (Taylor et al., 1998; Wirth et al., 1997). Moreover, the expression of Lewis antigens by $H$. pylori displays phenotypic (phase) variation (Appelmelk et al., 1998; Wirth et al., 1999). The molecular mimicry and phase variation of $H$. pylori Lewis antigen expression may contribute to the adaptation of this human gastric pathogen to the host environment. The expression of Lewis antigens by $H$. pylori has also been suggested as a cause of autoimmunity involved in the pathogenesis of chronic type B gastritis and gastric and duodenal ulcers (Appelmelk et al., 1996). 
(a)

\section{Type 1 series}

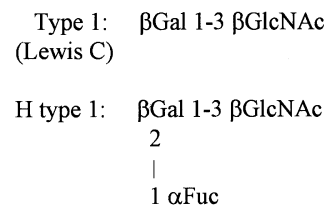

Lewis a: $\quad \beta$ Gal 1-3 $\beta$ GlcNAc 4

$1 \alpha$ Fuc

Lewis b: $\quad \beta$ Gal 1-3 $\beta$ GlcNAc

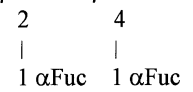

Type 2 series

LacNAc: $\quad \beta$ Gal 1-4 $\beta$ GlcNAc (Type 2)

H type 2: $\quad \beta$ Gal 1-4 $\beta$ GlcNAc 2

$1 \alpha$ Fuc

Lewis X: $\quad \beta$ Gal 1-4 $\beta$ GlcNAc 3

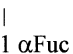

Lewis Y: $\quad \beta$ Gal 1-4 $\beta$ GlcNAc $\begin{array}{ll}2 & 3 \\ 1 & \mid \\ 1 \alpha \text { Fuc } & 1 \alpha \text { Fuc }\end{array}$

(b)

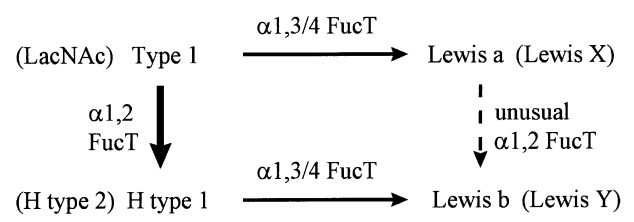

Fig. 1. Structural relationship between Lewis antigens (a) and the biosynthetic pathways operating in mammalian cells (b). The pathways shown in (b) are adapted from the references of Avent (1997) and Herry et al. (1995), and the corresponding type 2 structures are included in parentheses. The dashed arrow represents the unusual pathway for the synthesis of Lewis $Y$ and Lewis b. Abbreviations for sugars: Gal, galactose; GlcNAc, $\mathrm{N}$-acetylglucosamine; Fuc, fucose.

In mammalian cells, the synthesis of Lewis antigens is regulated by several glycosyltransferases that add monosaccharides to a precursor molecule in a sequential fashion (Fig. 1b) (for reviews see Avent, 1997; Herry et al., 1995; Kleene \& Berger, 1993; Watkins, 1995). Lewis a $\left(\mathrm{Le}^{\mathrm{a}}\right)$ is synthesized from the type 1 precursor by an $\alpha 1,3 / 4$-fucosyltransferase (FucT) encoded by fut-3 (Le gene), and the same enzyme is responsible for the synthesis of Lewis $b\left(\mathrm{Le}^{\mathrm{b}}\right)$ from $\mathrm{H}$ type 1 . At least five different human FucT genes (fut-3, fut-4, fut-5, fut-6 and fut-7) have been identified that encode enzymes involved in the synthesis of $\mathrm{Le}^{\mathrm{x}}$ and Le $\mathrm{Le}^{\mathrm{a}}$ structures (Herry et al., 1995). $\alpha 1,2$-FucT transfers fucose to the terminal $\beta \mathrm{Gal}$ unit of precursor chains (type 1 or LacNAc) to form $\mathrm{H}$ antigens. At least two distinct $\alpha 1,2$-FucTs are present in human tissues. The $\alpha 1,2$-FucT encoded by the $\mathrm{H}$ gene (fut-1) is active mainly on erythrocyte membranes, while the $\alpha 1,2$-FucT encoded by the Se gene ( $f u t-2)$ catalyses the synthesis of $\mathrm{H}$ antigen mainly in epithelial cells and in body fluids such as saliva (Avent, 1997). Classical models assume that difucosylated structures $\left(\mathrm{Le}^{\mathrm{b}}\right.$ or $\mathrm{Le}^{\mathrm{Y}}$; see Fig. 1a) are synthesized through sequential action of the $\alpha 1,2-$ and $\alpha 1,3 / 4-F u c T$ s through $\mathrm{H}$ determinants (Avent, 1997; Watkins, 1995). However, unusual $\alpha 1,2$-FucT activity that synthesizes $\mathrm{Le}^{\mathrm{b}}$ from $\mathrm{Le}^{\mathrm{a}}$ or $\mathrm{Le}^{\mathrm{Y}}$ from $\mathrm{Le}^{\mathrm{X}}$ has been found in some human cancer cells or tissues (Blaszczyk-Thurin et al., 1988; Yazawa et al., 1993), and recently such an unusual (the third type) $\alpha 1,2-\mathrm{FucT}$ was also found in the normal cells of rabbit (Hitoshi et al., 1996).

While the biosynthesis of Lewis antigens in mammalian cells is widely studied, little is known about the synthetic pathways and the genes/enzymes involved in biosynthesis of Lewis antigens in H. pylori. Recently, a gene encoding $\alpha 1,3$-FucT in $H$. pylori was identified and characterized (Ge et al., 1997; Martin et al., 1997), and the whole genome sequences (Alm et al., 1999; Tomb et al., 1997) demonstrated the existence of two copies of this gene in the genome of H. pylori. So far, neither a gene encoding $\alpha 1,4$-FucT nor any enzyme activity of $\alpha 1,4-F u c T$ has been identified in H. pylori. In a previous study, we analysed the putative $H$. pylori $(\mathrm{Hp}) \propto 1,2-$ FucT-encoding gene (fucT2) and demonstrated its essential role in the synthesis of $\mathrm{Le}^{\mathrm{Y}}$ by knock-out mutagenesis (Wang et al., 1999). Here we report the development of a sensitive assay system for detection of Hp $\alpha 1,2-F u c T$ enzyme activity, and the characterization of its properties and functions in the synthesis of Lewis antigens. Different $H$. pylori strains express different types of fucT2 genes in which a frameshift mutation at the DNA level and ribosomal frameshifting at the translation level may be involved (Wang et al., 1999). We have proceeded to examine an enzyme encoded by a variant of the fucT2 gene. Furthermore, we were able to determine the enzyme activities directly from some $H$. pylori isolates by using selected acceptors, even though the activities are present at very low levels.

\section{METHODS}

Bacterial strains and media. H. pylori strains UA802, UA1182, UA1195 and UA1234 used in this study were clinical isolates from the University of Alberta Hospital. H. pylori cells were cultured on BHI-YE $(3.7 \%$ brain heart infusion with $0.3 \%$ yeast extract and $5 \%$ animal serum) agar plates or in BHI-YE broth under microaerobic conditions. Escherichia coli strain CLM4 [ $\Delta r e c A$ lacZ trp $\Delta(s b c B-r f b)$ upp rel rpsL] (Yao et al., 1992) carrying the plasmid pGP1-2 (Tabor \& Richardson, 1985) was used for overexpression of $\mathrm{Hp} f u c T 2$ genes. Plasmid pGP1-2 carries the gene encoding T7 RNA polymerase under the control of a heat-inducible Plac promoter. LB medium, M9 medium and a supplemented M9 medium (Sambrook et al., 1989) were used for growth of E. coli cells. Ampicillin $(100 \mu \mathrm{g}$ $\left.\mathrm{ml}^{-1}\right)$, kanamycin $\left(40 \mu \mathrm{g} \mathrm{ml}^{-1}\right)$ or rifampicin $\left(200 \mu \mathrm{g} \mathrm{ml}^{-1}\right)$ were added to the above media, if appropriate, for growth of plasmid-containing cells and for expression of plasmidencoded proteins.

DNA manipulation techniques. Standard DNA manipulation techniques, including the isolation, transformation and restriction enzyme digestion analysis of plasmid DNA, as well as partial DNA sequencing, were as detailed by Sambrook et al. (1989).

Overexpression of the $\mathrm{Hp}$ FucT in E. coli. In a typical experiment, E. coli CLM4(pGP1-2) habouring a plasmid carrying an Hp fucT gene (pBKHp763fucT39, pGEMH2, pGEMI6 or pGEMB3) was grown in $25 \mathrm{ml}$ liquid LB medium with appropriate antibiotics (kanamycin and ampicillin) at $30{ }^{\circ} \mathrm{C}$ to an $\mathrm{OD}_{600}$ of $0 \cdot 5-0 \cdot 7$. After being collected, the cells were washed once with M9 medium, resuspended in $5 \mathrm{ml}$ supplemented M9 medium, and further incubated at $30^{\circ} \mathrm{C}$ for 
$1 \mathrm{~h}$. To induce the expression of the fucT gene, the culture was shifted to $42{ }^{\circ} \mathrm{C}$ by adding $5 \mathrm{ml}$ prewarmed $\left(55^{\circ} \mathrm{C}\right)$ supplemented M9 medium. After incubation at $42{ }^{\circ} \mathrm{C}$ for $15 \mathrm{~min}$, rifampicin was added to a final concentration of $200 \mu \mathrm{g} \mathrm{ml}{ }^{-1}$, and cell growth was continued at $42{ }^{\circ} \mathrm{C}$ for $20 \mathrm{~min}$.

For analysis of the protein by SDS-PAGE, a small aliquot $(0 \cdot 5$ $\mathrm{ml}$ ) of the cell culture was taken, and $2 \cdot 5 \mu \mathrm{l}\left[{ }^{35} \mathrm{~S}\right]$ methionine $\left(4.35 \times 10^{13} \mathrm{~Bq} \mathrm{mmol}{ }^{-1}, 3.7 \times 10^{8} \mathrm{~Bq} \mathrm{ml}^{-1}\right.$, New England Nuclear) was added. After further growth at $30^{\circ} \mathrm{C}$ for $30 \mathrm{~min}$, the cells were harvested, resuspended in $100 \mu \mathrm{l}$ sample buffer (50 mM Tris/HCl, pH 6.8; 1\%, w/v, SDS; 20 mM EDTA; $1 \%, \mathrm{v} / \mathrm{v}$, mercaptoethanol; $10 \%, \mathrm{v} / \mathrm{v}$, glycerol), and boiled for $3 \mathrm{~min}$ before loading on to the gel. For the preparation of the sample for the enzyme assay, the remaining part (major aliquot, $9.5 \mathrm{ml}$ ) of the cell culture after induction was further incubated at $30{ }^{\circ} \mathrm{C}$ for $30 \mathrm{~min}$, then harvested. The cells were washed with $1.5 \mathrm{ml} 20 \mathrm{mM}$ HEPES (pH 7.0), and resuspended in $1.5 \mathrm{ml}$ of this buffer supplemented with $0.5 \mathrm{mM}$ PMSF.

Preparation of cell lysates or cell extracts for the fucosyltransferase assay. The E. coli cells containing overproduced Hp FucT proteins, which were in HEPES buffer with PMSF as described above, were disrupted with a French press at 7000 p.s.i. $(48 \mathrm{kPa})$ at $4{ }^{\circ} \mathrm{C}$. The cell lysates were used directly for enzyme assays. For determining the location of the enzyme activities, the cytoplasmic and membrane fractions were separated as follows. The cell lysates were centrifuged at $13000 \mathrm{~g}$ at $4{ }^{\circ} \mathrm{C}$ for $10 \mathrm{~min}$. The cell debris were discarded and the supernatant was subjected to ultracentrifugation at $128000 \mathrm{~g}$ (Beckman TL100/rotor 100.2) at $4^{\circ} \mathrm{C}$ for $1 \mathrm{~h}$. The supernatant was collected as the cytoplasmic fraction. The membrane pellets were resuspended in a small volume of the same buffer and treated with $1 \mathrm{M} \mathrm{NaCl}$.

For determining the enzyme activity from $H$. pylori cells, cells grown for $3 \mathrm{~d}$ in $25 \mathrm{ml}$ BHI-YE broth were harvested and washed with $5 \mathrm{ml} 20 \mathrm{mM}$ HEPES buffer (pH 7·0). Finally the cells were resuspended in $2 \mathrm{ml}$ of the same HEPES buffer plus $0.5 \mathrm{mM}$ PMSF. The H. pylori cells were disrupted with a French press as described above for E. coli cells, and the cell lysates were directly used for enzyme assays.

Fucosyltransferase assay. Assays of $\mathrm{Hp} \alpha 1,2-$ and $\alpha 1,3$-FucT activities were carried out according to the method described by Chan et al. (1995) with some modifications. Reactions were conducted at $37^{\circ} \mathrm{C}$ for $20 \mathrm{~min}$ in a volume of $20 \mu \mathrm{l}$ containing $1.8 \mathrm{mM}$ acceptor, $50 \mu \mathrm{M}$ GDP-fucose, 60000 d.p.m. GDP$\left[{ }^{3} \mathrm{H}\right]$ fucose, $20 \mathrm{mM}$ HEPES buffer (pH 7.0), $20 \mathrm{mM} \mathrm{MnCl}_{2}$, $0 \cdot 1 \mathrm{M} \mathrm{NaCl}, 35 \mathrm{mM} \mathrm{MgCl}_{2}, 1 \mathrm{mM} \mathrm{ATP}, 5 \mathrm{mg} \mathrm{BSA} \mathrm{ml}^{-1}$, and $6 \cdot 2 \mu \mathrm{l}$ of the enzyme preparation. The acceptors used in this study were: LacNAc $[\beta$ Gal1- $4 \beta$ GlcNAc $]$, Le $^{\mathrm{x}}[\beta \mathrm{Gal1}-4(\alpha \mathrm{Fuc} 1-$ 3) $\beta \mathrm{GlcNAc}]$, type $1[\beta \mathrm{Gal1}-3 \beta \mathrm{GlcNAc}]$ and $\mathrm{Le}^{\mathrm{a}}[\beta \mathrm{Gal1}-$ $3(\alpha$ Fuc1-4) $\beta$ GlcNAc]. These acceptors were provided by Dr O. Hindsgaul, Department of Chemistry, University of Alberta. GDP-[ $\left.{ }^{3} \mathrm{H}\right]$ fucose $\left(1.9 \times 10^{11} \mathrm{~Bq} \mathrm{ml}^{-1} \mathrm{mmol}^{-1}\right)$ was obtained from American Radiolabelled Chemicals. Sep-Pak Plus C-18 reverse-phase cartridges were purchased from Waters. For calculation of the specific activity of the enzyme [micro-units $(\mu \mathrm{U})$ per mg protein], protein concentrations of the cell extracts were determined with a BCA protein assay kit (Pierce) using BSA as a standard according to the supplier's instructions.

Capillary electrophoresis assays. These assays were performed to identify the products synthesized by the protein preparation of E. coli cells overexpressing UA802 $\alpha 1,2-F u c T$. For a negative control, the protein preparation of $E$. coli cells containing pGEM vector was used. The reaction mixture, in a volume of $20 \mu \mathrm{l}$, contained $8 \mu \mathrm{l}$ of the protein preparation, $1.8 \mathrm{mM}$ acceptor labelled with tetramethylrhodamine (TMR), $1.8 \mathrm{mM}$ GDP-fucose, $20 \mathrm{mM}$ HEPES buffer (pH 7.0), $20 \mathrm{mM}$ $\mathrm{MnCl}_{2}, 0 \cdot 1 \mathrm{M} \mathrm{NaCl}, 35 \mathrm{mM} \mathrm{MgCl}, 1 \mathrm{mM}$ ATP and $5 \mathrm{mg}$ BSA ml $\mathrm{m}^{-1}$. The reaction was carried out at $37^{\circ} \mathrm{C}$ for $20 \mathrm{~min}$. The sample was applied to a conditioned Sep-Pak C-18 Cartridge (Palcic et al., 1988), washed with $20 \mathrm{ml}$ water, and the TMR-labelled oligosaccharides were eluted with $3 \mathrm{ml}$ HPLC-grade methanol. Subsequently, the sample was prepared and analysed by capillary electrophoresis by injecting $12 \mathrm{pl}$ onto a column $(60 \mathrm{~cm}$ long $\times 10 \mu \mathrm{m}$ i.d. $)$ at $1 \mathrm{kV}$ for $5 \mathrm{~s}$ as described previously (Chan et al., 1995). The electrophoretic separations were performed at a running voltage of $400 \mathrm{~V} \mathrm{~cm}^{-1}$.

\section{RESULTS}

\section{Overexpression of $\mathrm{Hp} \alpha 1,2$-FucT protein in $E$. coli}

Initially, we found it was very difficult to detect $\alpha 1,2-$ FucT activity from $H$. pylori, due to the low level of its expression and the instability of the protein. Therefore, we sought to establish a system for overexpression of the Hp fucT2 gene in E. coli to obtain high yields of proteins. As described in Methods, the plasmid containing the Hp fucT2 gene under the control of the T7 promoter was transferred into E. coli CLM4(pGP1-2), and the expression of the gene was induced by shifting the host cells from 30 to $42{ }^{\circ} \mathrm{C}$ (Tabor \& Richardson, 1985). As a reference, we included a previously cloned Hp $\alpha 1,3$-FucT-encoding gene carried on the plasmid pBKHp763fucT39 (Ge et al., 1997). Using the E. coli CLM4(pGP1-2) gene expression system, we obtained the overexpressed Hp $\alpha 1,3$-FucT protein with an expected molecular mass of $52 \mathrm{kDa}$ (Fig. 2b, lane 1). The yield of the protein, in terms of the fraction of the FucT protein in the total proteins, was much higher than that reported previously (Ge et al., 1997), in which the gene was expressed in E. coli CSRDE3 cells with the induction by IPTG. Correspondingly, we detected a specific $\alpha 1,3-$ FucT activity of $1480 \mu \mathrm{U}$ (mg protein) $)^{-1}$ (in the wholecell extract) by using LacNAc as an acceptor (Table 1, A), which is much higher than those obtained before [26 $\mu \mathrm{U}$ (mg cytoplasmic protein $)^{-1}$ and $700 \mu \mathrm{U}$ (mg membrane protein $)^{-1}$. Similarly, a considerably high amount of $\alpha 1,2$-FucT protein $(33 \mathrm{kDa}$ ) was obtained from the expression of the cloned fucT2 gene in the plasmid pGEMI6 (Fig. 2, lane 5), which enabled us to detect $\alpha 1,2$-FucT activity.

\section{Acceptor specificity of $\mathrm{Hp} \propto 1,2-\mathrm{FucT}$}

Plasmid pGEMI6 carries the prototype fucT2 gene from H. pylori UA802, which produces a high level of $\mathrm{Le}^{\mathrm{Y}}$. The disruption of this gene in the bacterium resulted in no $\mathrm{Le}^{\mathrm{Y}}$ production, suggesting that its gene product is involved in $\mathrm{Le}^{\mathrm{Y}}$ synthesis (Wang et al., 1999). Initially, we quantified the $\alpha 1,2$-FucT activity by using LacNAc and $\mathrm{Le}^{\mathrm{X}}$ as acceptors, the two potential substrates of $\alpha 1,2-$ FucT for the synthesis of $\mathrm{Le}^{\mathrm{Y}}$ (Fig. 1). Surprisingly, almost no activity was detected using LacNAc as an acceptor, whereas considerable activity was observed for the monofucosylated $\mathrm{Le}^{\mathrm{X}}$ acceptor (Table 1, B). The 
Table 1. Activities of $H$. pylori fucosyltransferases detected from the proteins overexpressed in E. coli

\begin{tabular}{|c|c|c|c|c|c|}
\hline & $\begin{array}{l}\text { Overexpressed protein* } \\
\text { (plasmid construct) }\end{array}$ & Acceptor & $\begin{array}{c}\text { Proposed } \\
\text { product }\end{array}$ & $\begin{array}{c}\text { Specific } \\
\text { activity } \\
\left(\mu \mathrm{U} \mathrm{mg}^{-1}\right) \dagger\end{array}$ & $\begin{array}{c}\text { Relative } \\
\text { activity }(\%) \neq\end{array}$ \\
\hline A & $\begin{array}{l}\alpha 1,3-F u c T \\
(\text { pBKHp763fucT39) }\end{array}$ & LacNAc & $\operatorname{Le}^{\mathrm{x}}$ & 1480 & \\
\hline B & $\begin{array}{l}\alpha 1,2-\text { FucT (UA802) } \\
(\text { pGEMI6) }\end{array}$ & $\begin{array}{c}\text { LacNAc } \\
\text { Le }^{\mathrm{x}} \\
\text { Type } 1 \\
\text { Le }^{\mathrm{a}}\end{array}$ & $\begin{array}{c}\text { H type } 2 \\
\text { Le }^{\mathrm{Y}} \\
\mathrm{H} \text { type } 1 \\
\text { Le }^{\mathrm{b}}\end{array}$ & $\begin{array}{c}14 \pm 8 \\
150 \pm 33 \\
309 \pm 28 \\
301 \pm 13\end{array}$ & $\begin{array}{c}4 \cdot 5 \\
49 \\
100 \\
97\end{array}$ \\
\hline $\mathrm{C}$ & $\begin{array}{l}\alpha 1,2 \text {-FucT }(\mathrm{UA} 802) \\
(\mathrm{N} \text {-truncated, pGEMH2) }\end{array}$ & $\begin{array}{c}\text { LacNAc } \\
\text { Le }^{\mathrm{x}} \\
\text { Type } 1 \\
\text { Le }^{\mathrm{a}}\end{array}$ & $\begin{array}{c}\text { H type } 2 \\
\text { Le }^{\mathrm{Y}} \\
\mathrm{H} \text { type } 1 \\
\text { Le }^{\mathrm{b}}\end{array}$ & $\begin{array}{l}0 \\
0 \\
0 \\
0\end{array}$ & $\begin{array}{l}0 \\
0 \\
0 \\
0\end{array}$ \\
\hline $\mathrm{D}$ & $\begin{array}{l}\alpha 1,2-F u c T(26695) \\
(\text { pGEMB3) }\end{array}$ & $\begin{array}{c}\text { LacNAc } \\
\text { Le }^{\mathrm{x}} \\
\text { Type } 1 \\
\text { Le }^{\mathrm{a}}\end{array}$ & $\begin{array}{c}\text { H type } 2 \\
\text { Le }^{\mathrm{Y}} \\
\mathrm{H} \text { type } 1 \\
\text { Le }^{\mathrm{b}}\end{array}$ & $\begin{array}{c}0 \\
0 \\
23 \pm 17 \\
16 \pm 10\end{array}$ & $\begin{array}{l}0 \\
0 \\
7 \cdot 4 \\
5 \cdot 2\end{array}$ \\
\hline
\end{tabular}

*E. coli whole-cell extract containing the overexpressed H. pylori FucT protein was used for the enzyme assay.

† A micro-unit $(\mu \mathrm{U})$ of the enzyme is expressed as the amount of enzyme that converts 1 pmol of acceptor to product per min. Specific activity was obtained by dividing the total activity $(\mu \mathrm{U})$ by the total protein content $(\mathrm{mg})$ in the whole-cell extract. The data were averaged from at least three independent determinations; standard deviations are shown.

$\ddagger$ Percentage activity relative to that of UA802 $\alpha 1,2$-FucT on its best substrate, type 1 .

specific activity of $\alpha 1,2-$ FucT was much lower than that of $\alpha 1,3$-FucT (Table $1, \mathrm{~A})$.

In mammalian cells, the same $\alpha 1,2$-FucT enzyme ( $\mathrm{H}$ or Se, tissue-specific) is normally responsible for the synthesis of both $\mathrm{H}$ type 1 and $\mathrm{H}$ type 2 structures (Sarnesto et al., 1990, 1992). To determine whether the Hp $\alpha 1,2-$ FucT is also involved in the synthesis of $\mathrm{Le}^{\mathrm{b}}$, we measured its activity with type 1 oligosaccharide acceptors (Table 1, B). Even though UA802 does not express type 1 Lewis antigen, its $\alpha 1,2$-FucT enzyme can transfer fucose to type 1 and $\mathrm{Le}^{\mathrm{a}}$ acceptors. Compared to $\mathrm{Le}^{\mathrm{x}}$, type 1 and $\mathrm{Le}^{\mathrm{a}}$ are even more efficient substrates for $\mathrm{Hp}$ $\alpha 1,2$-FucT (twofold more active). Thus, Hp $\alpha 1,2-$ FucT can also synthesize $\mathrm{H}$ type 1 and $\mathrm{Le}^{\mathrm{b}}$.

\section{Analysis of the reaction products of $\mathrm{Hp} \alpha 1,2$-FucT by capillary electrophoresis}

The reaction products synthesized from different acceptors by the $\mathrm{Hp} \alpha 1,2$-FucT were further characterized by capillary electrophoresis with laser-induced fluorescence detection. The reaction mixture contained the overproduced UA802 $\alpha 1,2-F u c T$ protein (from the pGEMI6 clone), GDP-fucose, and different acceptors labelled with TMR. The results (Fig. 3) confirmed the data from the enzyme assay using radioactive labelled GDP-fucose (Table 1, B) by identifying the products of the reactions.

When using LacNAc as an acceptor (Fig. 3a, trace A), no reaction product representing $\mathrm{H}$ type 2 was observed, suggesting that LacNAc is not a substrate for $\mathrm{Hp} \alpha 1,2-$ FucT. In the reaction using $\mathrm{Le}^{\mathrm{x}}$ as an acceptor (Fig. 3a, trace B), a small new peak was produced, which comigrated with a synthetic $\mathrm{Le}^{\mathrm{Y}}$-TMR (standard $\mathrm{Le}^{\mathrm{Y}}$ ) in the electropherogram, indicating that this new peak represents the $\mathrm{Le}^{\mathrm{Y}}$ product synthesized from $\mathrm{Le}^{\mathrm{X}}$ by $\mathrm{Hp}$ $\alpha 1,2-F u c T$. Similarly, by using type 1 or Le as acceptors (Fig. 3b), new peaks co-migrating with authentic products, $\mathrm{H}$ type 1 or $\mathrm{Le}^{\mathrm{b}}$ respectively, were observed. As negative controls, the protein extract from the E. coli CLM4(pGP1-2) clone containing the pGEM vector without the Hp fucT2 gene was used in the reactions for each acceptor tested above; no peaks for the products of $\alpha 1,2-$ FucT were observed (data not shown).

\section{Hp $\propto 1,2$-FucT is a soluble protein}

DNA sequence analysis predicted the Hp $\alpha 1,2$-FucT to be a hydrophilic protein (Wang et al., 1999), and the same is true for $\mathrm{Hp} \alpha 1,3-\mathrm{FucT}$ (Ge et al., 1997). However, the determination of $\mathrm{Hp} \alpha 1,3$-FucT activity from the overexpressed proteins demonstrated that the majority of the activity was present in the membrane fraction (Ge et al., 1997). To delineate the cellular location of the Hp $\alpha 1,2$-FucT activity, cytoplasmic and membrane fractions of $E$. coli cells overproducing $\mathrm{Hp}$ $\alpha 1,2$-FucT proteins were prepared as described in Methods. The activity in both fractions was determined 
(a)
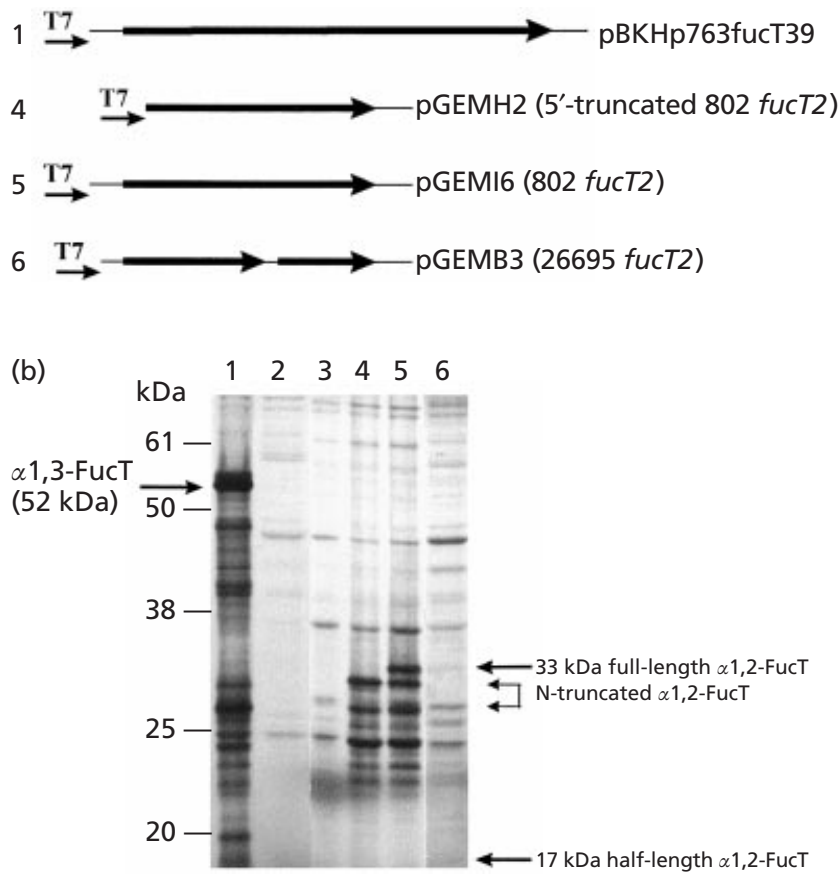

Fig. 2. Overexpression of $H$. pylori fucosyltransferases in $E$. coli. (a) Plasmid constructs containing intact or partial $H$. pylori fucT genes. Heavy arrows represent the predicted ORFs, and the thin lines indicate the flanking DNA regions that have been cloned together with the coding region into the vector. The small arrows indicate the direction of transcription from the T7 promoter. pBKHp763fucT39 was from $\mathrm{Ge}$ et al. (1997); pGEMH2, pGEMI6 and pGEMB3 were described previously (Wang et al., 1999). The numbers on the left for each plasmid construct correspond to the lane numbers in (b). (b) Autoradiograph of a $0.1 \%$ SDS- $12 \%$ polyacrylamide gel analysing the proteins overexpressed from various plasmid constructs in E. coli CLM4(pGP1-2). As the same volume of cell extract was loaded on each lane, there could be some variation in the amount $(\mathrm{mg})$ of the proteins, especially for the sample in lane 1 (pBKHp763fucT39), which was expressed from a different vector. Lane 1, expression of pBKHp763fucT39 produced a high amount of $52 \mathrm{kDa} \alpha 1,3-\mathrm{FucT}$. Lane 2, no plasmid construct. Lane 3, pGEM-T vector without fucT2 gene. Lanes 4, 5 and 6, expression of $\alpha 1,2-\mathrm{FuCT}$ from plasmid constructs pGEMH2, pGEMI6 and pGEMB3, respectively. The full-length protein $(33 \mathrm{kDa})$ marked by an arrow on the right was overexpressed from intact UA802 fucT2 gene (lane 5) but not from the 5'truncated gene (lane 4). Two major bands with smaller molecular masses, which represent $\mathrm{N}$-terminally truncated $\alpha 1,2-$ FucT, are indicated. The expression of 26695 fucT2 gave rise to a faint band of $33 \mathrm{kDa}$ full-length $\alpha 1,2$-FucT and a faint band of $17 \mathrm{kDa}$ half-length $\alpha 1,2$-FucT (lane 6). The molecular mass markers (BenchMark Prestained Protein Ladder, GiboBRL) are indicated on the left.

using Le ${ }^{\mathrm{x}}$ or type 1 as acceptors (Table 2). There was no detectable activity in the membrane fraction when using $\mathrm{Le}^{\mathrm{X}}$ as an acceptor. By using type 1 as an acceptor, a very low amount of activity (negligible) was detected in the membrane fraction, which accounted for less than $3 \%$ of the total activity. These results indicated that $\mathrm{Hp}$ $\alpha 1,2-\mathrm{FucT}$ is a soluble cytoplasmic protein. Compared to the data shown in Table 1, which were obtained from measurement of immediate cell lysates, the specific
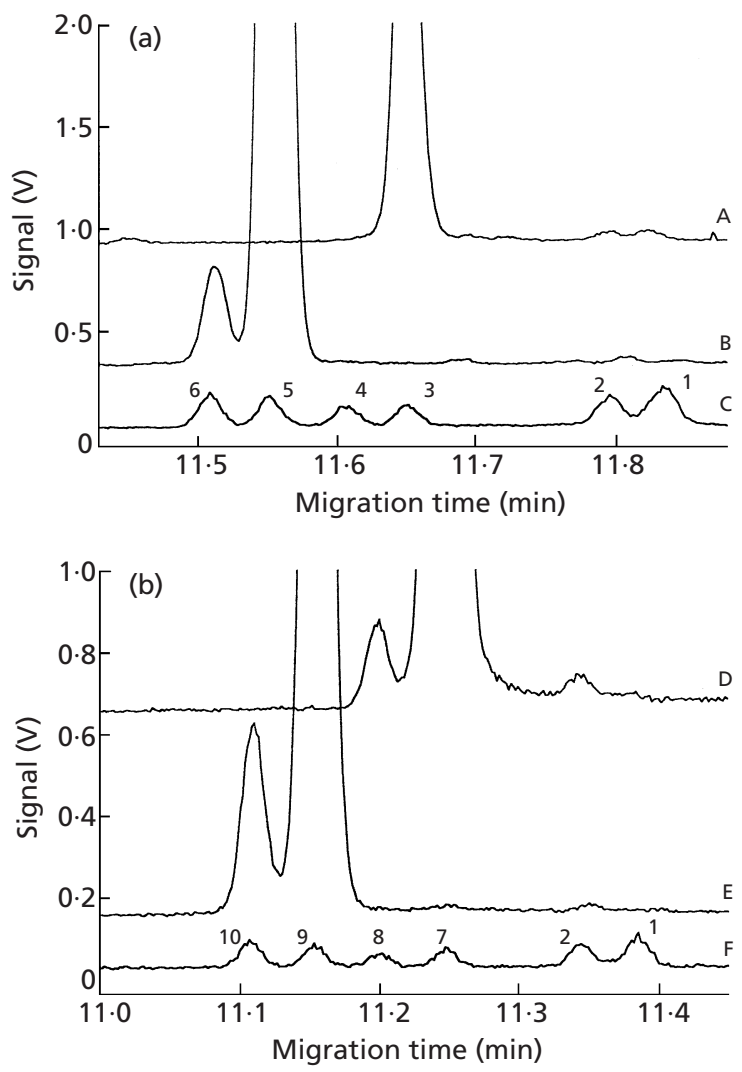

Fig. 3. Identification of the reaction products of $\mathrm{Hp} \alpha 1,2$-FucT by capillary electrophoresis. The enzyme used here was the overexpressed UA802 $\alpha 1,2$-FucT protein. The reactions were carried out as described in Methods. (a) Reactions on type 2 substrates LacNAc (trace A) and Le $^{\mathrm{X}}$ (trace B). (b) Reactions on type 1 substrates type 1 (trace D) and Le ${ }^{a}$ (trace E). Lines $C$ and $F$ represent the standard TMR-labelled oligosaccharides: 1, linking arm; 2, GlcNAC; 3, LacNAc; 4, H type $2 ; 5, \operatorname{Le}^{\mathrm{X}} ; 6, \mathrm{Le}^{\mathrm{Y}} ; 7$, type $1 ; 8, \mathrm{H}$ type $1 ; 9$ Le $^{\mathrm{a}} ; 10$ Le $^{\mathrm{b}}$. All traces are $y$-offset for clarity.

activities $\left[\mu \mathrm{U}(\mathrm{mg} \text { protein })^{-1}\right]$ obtained here are much lower (three- to fourfold). Most probably, many enzyme activities were lost in the procedure for separating cytoplasmic and membrane fractions.

\section{$\mathrm{N}$-terminally truncated $\mathrm{Hp} \alpha 1,2-\mathrm{FucT}$ has no activity}

As expected, the expression of the plasmid pGEMH2, which carries a $5^{\prime}$-truncated fucT2 gene from UA802, did not produce the full-length protein (Fig. 2, lane 4). However, two major protein bands with molecular masses smaller than $33 \mathrm{kDa}$ were obtained. These two bands were also observed in cells harbouring pGEMI6 containing the entire fucT2 gene (lane 5), but not in cells containing the pGEM vector alone (lane 3$)$. In the $5^{\prime}$ region of the Hp fucT2 gene (GenBank accession no. AF076779), we identified two additional putative translation start codons (ATG) with upstream ShineDalgarno sequences. Translation starting from them could produce the identified N-terminal truncated proteins. Determination of the enzyme activity from the 
Table 2. Enzyme activities of $H$. pylori $\alpha 1,2-$ FucT in cytoplasmic and membrane fractions

\begin{tabular}{|lccccc|}
\hline $\begin{array}{l}\text { Expt } \\
\text { no. }\end{array}$ & $\begin{array}{c}\text { Acceptor } \\
\text { used }\end{array}$ & $\begin{array}{c}\text { Protein } \\
\text { fraction* }\end{array}$ & $\begin{array}{c}\text { Specific activity } \\
{[\mu \mathrm{U}(\mathbf{m g}} \\
\left.\text { protein })^{-1}\right]\end{array}$ & $\begin{array}{c}\text { Total activity } \\
(\boldsymbol{\mu} \mathrm{U}) \dagger\end{array}$ & $\begin{array}{c}\text { Relative activity } \\
(\%) \neq\end{array}$ \\
\hline 1 & Le $^{\mathrm{x}}$ & cytoplasm & 38 & 49 & 100 \\
& & membrane & 0 & 0 & 0 \\
2 & Le & cytoplasm & 41 & 54 & 100 \\
& Type 1 & membrane & 0 & 0 & 97 \\
& cytoplasm & 78 & 108 & 3 \\
\hline
\end{tabular}

*In a typical experiment described in Methods, each protein sample was prepared from $25 \mathrm{ml}$ cell culture of E. coli CLM4(pGP1-2, pGEMI6) containing the overexpressed UA802 $\alpha 1,2-\mathrm{FucT}$. The cytoplasmic and membrane fractions were separated as described in Methods.

† Total activity $(\mu \mathrm{U})$ in each protein sample was derived from a $25 \mathrm{ml}$ cell culture.

$\ddagger$ Percentage of the total activity in the cytoplasmic or membrane fraction.

overexpressed protein extract of E. coli CLM4(pGP1-2) harbouring pGEMH2 demonstrated no activity for the $\mathrm{N}$-terminally truncated $\alpha 1,2$-FucT proteins (Table $1, \mathrm{C}$ ). Therefore, only the full-length protein has functional fucosyltransferase activity. Production of some Ntruncated $\alpha 1,2-\mathrm{FucT}$ in vivo may be an additional mechanism for down-regulating the enzyme activity, contributing to the variable expression of Lewis antigens in H. pylori.

\section{Lower-level expression of the $\alpha 1,2$-FucT from $H$. pylori strain 26695}

The fucT2 gene in H. pylori 26695 is a variant because it is split into two potential smaller ORFs due to frameshift mutation at the centre of the gene (Fig. 2a, pGEMB3). In vitro expression of this gene has demonstrated that the full-length protein (equivalent to that of prototype UA802 $\alpha 1,2$-FucT) can be produced from this gene, most probably by a mechanism of translational frameshifting (the frequency was around $50 \%$ ) (Wang et al., 1999). In this study, the plasmid pGEMB3 carrying the 26695 fucT2 gene was transferred into E. coli CLM4(pGP1-2), and the gene was expressed in the same way as described above. In contrast to UA802 fucT2 gene (pGEMI6; Fig. 2, lane 5), the expression of the 26695 fucT2 gene produces a much lower amount of the full-length protein (Fig. 2, lane 6). Concomitantly, an additional faint band at $17 \mathrm{kDa}$, representing the halflength $\alpha 1,2$-FucT, was observed. This suggested that the expression of the gene in vitro may be very different from that in vivo.

In agreement with the low amount of the expressed protein, a low level of enzyme activity was detected for $26695 \propto 1,2-F u c T$ (Table 1, D). Using LacNAc or Le ${ }^{\mathrm{x}}$ as acceptor, the activity was undetectable. Using type 1 or $\mathrm{Le}^{\mathrm{a}}$ as acceptor, a low activity of about $20 \mu \mathrm{U}(\mathrm{mg}$ protein $)^{-1}$ was detected, which is only about $7 \%$ of the activity of UA802 $\alpha 1,2-F u c T$. Considering that UA802 $\alpha 1,2$-FucT has a lower activity on $\mathrm{Le}^{\mathrm{X}}$ than on type 1 or
$\mathrm{Le}^{\mathrm{a}}$, it is not surprising that the activity of $26695 \propto 1,2-$ FucT on $\mathrm{Le}^{\mathrm{X}}$ is too low to be detected.

\section{Detection of $\alpha 1,2-$ FucT activity directly from $H$. pylori cell extracts}

After the characterization of the $\mathrm{Hp} \alpha 1$,2-FucT protein overproduced in E. coli, we attempted to detect the enzyme activity directly from $H$. pylori cells, which would be useful for screening high $\alpha 1,2$-FucT-producing strains. Two major difficulties hinder the achievement of this goal: (i) the expression level of the enzyme in natural H. pylori cells is very low; (ii) other fucosyltransferases (mainly $\alpha 1,3$-FucT), which co-exist in $H$. pylori cell extracts and have much higher activity than $\alpha 1,2$-FucT, interfere with the enzyme assay when using some acceptors such as LacNAc that are not specific for $\alpha 1,2$-FucT. Therefore, we analysed the enzyme activity from different strains and using different acceptors. Finally, we succeeded in detecting very low levels of $\alpha 1,2$-FucT activities from some $\mathrm{Le}^{\mathrm{Y}}$-producing $H$. pylori strains (Table 3 ).

First, using LacNAc as an acceptor, both cell extracts of the wild-type UA802 and its fucT2 knock-out mutant $(802 \Delta \mathrm{H})$ gave a very high level of activity [around $1000 \mu \mathrm{U}$ (mg protein $)^{-1}$; not shown]. This activity represents that of $\alpha 1,3-\mathrm{FucT}$, because (i) in $802 \Delta \mathrm{H}$ cells the $\alpha 1,2$-FucT-encoding gene is disrupted, but the $\alpha 1,3-$ FucT-encoding gene is intact; and (ii) LacNAc is not a substrate for $\alpha 1,2$-FucT, but is an excellent substrate for $\alpha 1,3$-FucT. A true activity of $\alpha 1,2-$ FucT, even though low, was demonstrated by using $\mathrm{Le}^{\mathrm{X}}$ or type 1 as acceptor. In agreement with the observation that the overexpressed $H$. pylori $\alpha 1,2$-FucT has highest activity on type 1 acceptor (Table 1, B, D), the $\alpha 1,2$-FucT activity from $H$. pylori cell extracts can be consistently detected by using type 1 as an acceptor. As these strains express $\mathrm{Le}^{\mathrm{Y}}$, the $\alpha 1,2-\mathrm{FucT}$ s are supposed to be functional on the $\mathrm{Le}^{\mathrm{x}}$ acceptor. However, for some strains such as UA802 and UA1195, the activity on $\mathrm{Le}^{\mathrm{X}}$ is too low to be 
Table 3. $\alpha 1,2$-FucT activities $\left(\mu \mathrm{U} \mathrm{mg}^{-1}\right.$ ) from different $H$. pylori cell extracts

\begin{tabular}{|c|c|c|c|}
\hline \multirow{2}{*}{$\begin{array}{l}\text { H. pylori } \\
\text { strain* }\end{array}$} & \multirow{2}{*}{$\begin{array}{c}\mathrm{Le}^{\mathrm{Y}} \\
\text { phenotype } †\end{array}$} & \multicolumn{2}{|c|}{ Acceptor used } \\
\hline & & $\mathrm{Le}^{\mathrm{X}}$ & Type 1† \\
\hline $802 \Delta \mathrm{H}$ & - & 0 & 0 \\
\hline UA802 & + & $0 \pm 5$ & $26 \pm 8$ \\
\hline UA1182 & + & $21 \pm 5$ & $22 \pm 7$ \\
\hline UA1195 & + & $0 \pm 4$ & $26 \pm 7$ \\
\hline UA1234 & + & $25 \pm 6$ & $21 \pm 6$ \\
\hline
\end{tabular}

$* 802 \Delta \mathrm{H}$ is a knock-out mutant of UA802 in which the fucT2 gene was disrupted by the insertion of a chloramphenicol-resistance cassette (Wang et al., 1999). It is used here as a negative control for the $\alpha 1,2$-FucT activity. The activities in other strains are the scores above this background value, and are averaged from three determinations, with standard deviations shown.

† The Le ${ }^{\mathrm{Y}}$ phenotypes are based on the ELISA results of these strains (Wang et al., 1999).

$\ddagger$ Type 1 could also be the substrate for $\alpha 1,4$-FucT. However, all the H. pylori strains listed here do not produce any $\mathrm{Le}^{\mathrm{a}}$ or $\mathrm{Le}^{\mathrm{b}}$. Therefore, it is unlikely that these $H$. pylori cell extracts contain any $\alpha 1,4-F u c T$ activity, as seen in $802 \Delta \mathrm{H}$. Thus, the enzyme activities detected here could be considered as those of $\alpha 1,2$-FucT.

detected in the current assay. For other strains such as UA1182 and UA1234, a similar activity on type 1 and on $\mathrm{Le}^{\mathrm{X}}$ was detected. This suggested that the enzymes from different strains may have different acceptor specificities. It should be noted, however, that the activities shown here are all at the minimal detectable level (about 10-15fold lower than those detected from the heterologously overexpressed protein extracts). Therefore, determination of the enzyme activity from $H$. pylori cell extracts may be helpful for identifying the strains that produce high level of $\alpha 1,2$-FucT, but may not be accurate for evaluating the acceptor specificity of the enzyme.

\section{DISCUSSION}

In this study, we identified the catalytic activity of $\alpha 1,2-$ FucT of $H$. pylori. We found that the enzyme is soluble and the activity is present in the cytoplasmic fraction. Under our assay conditions the enzyme activity can be consistently detected if it is above $10 \mu \mathrm{U}$ (mg protein $)^{-1}$, whereas an activity below that could be considered undetectable. According to this criterion, no activity was detected for the $\mathrm{N}$-terminally truncated $\alpha 1,2$-FucT, and a very low level of activity for the variant $\alpha 1,2$-FucT (from strain 26695). A considerably high level of activity was detected from the overproduced intact $\alpha 1,2$-FucT from $H$. pylori UA802, which shows a high level of expression of Lewis Y. However, compared with that of $\alpha 1,3$-FucT, the activity of $\alpha 1,2$-FucT is much lower (Table 1). In vivo, the expression of $\alpha 1,2$-FucT may be controlled at a very low level, because the $\mathrm{O}$-antigen of LPS structure normally consists of poly-Le ${ }^{\mathrm{x}}$ units and a single terminal $\mathrm{Le}^{\mathrm{Y}}$ (Monteiro et al., 1998). The low (a)

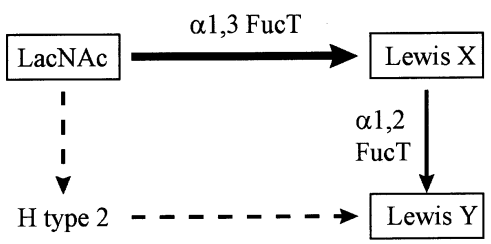

(b)

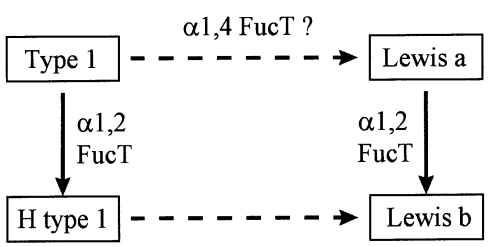

Fig. 4. Identified pathways for the synthesis of Lewis antigens in $H$. pylori. Lewis structures known to be expressed on the $H$. pylori cell surface are boxed. Solid arrows represent the fucosyltransferase activities that have been demonstrated in this study; the thickness of the arrows indicates the relative level of the enzyme activity. (a) $H$. pylori strains predominantly express $L^{X}$ and $L e^{Y}$, and do not appear to express $H$ type 2 . It seems reasonable that $H$. pylori utilizes $\operatorname{Le}^{X}$ to synthesize $\operatorname{Le}^{Y}$. For operation of this pathway $H$. pylori normally maintains a higher level of $\alpha 1,3$-FucT than of $\alpha 1,2$-FucT. (b) $H$. pylori $\alpha 1,2-$ FucT has the ability to transfer fucose to type 1 as well as to $\mathrm{Le}^{\mathrm{a}}$. The synthesis of $\mathrm{Le}^{\mathrm{b}}$ requires the concerted action of $\alpha 1,2-$ FucT with an as yet unidentified $\alpha 1,4$-FucT.

activity of $\alpha 1,2$-FucT in vitro, on the other hand, could be due to its instability. We noticed that $\mathrm{Hp} \alpha 1,2$-FucT lost its activity more rapidly than $\mathrm{Hp} \alpha 1,3$-FucT. Therefore, we routinely determined the enzyme activity immediately after the cells were lysed and used a short assay time (20 min).

Recently, we have shown that $H$. pylori mutants carrying a disrupted $f u c T 2$ gene (encoding $\alpha 1,2$-FucT) express more $\mathrm{Le}^{\mathrm{X}}$ than the wild-type cells (Wang et al., 1999). This phenomenon may suggest that $\mathrm{Le}^{\mathrm{X}}$ is the direct substrate for $\mathrm{Le}^{\mathrm{Y}}$ synthesis, but the mutagenesis experiment itself cannot exclude the other possible pathway of $\mathrm{Le}^{\mathrm{Y}}$ synthesis (via $\mathrm{H}$ type 2), because disruption of $\alpha 1,2$-FucT might lead to accumulation of LacNAc, providing more substrates for $\alpha 1,3$-FucT to synthesize $\operatorname{Le}^{\mathrm{X}}$ (Fig. 4a). Therefore, determination of activities of the fucosyltransferases responsible will be direct proof to distinguish between the two possible pathways. The observation in this study that $\mathrm{Le}^{\mathrm{X}}$ but not LacNAc is the substrate for the $\mathrm{Hp} \alpha 1,2$-FucT clearly indicated that $H$. pylori prefers to use the $\mathrm{Le}^{\mathrm{x}}$ pathway to synthesize $\mathrm{Le}^{\mathrm{Y}}$ (Fig. 4a). Other supporting evidence came from the enzyme assay for $\mathrm{Hp} \alpha 1,3$-FucT : (i) LacNAc is an excellent substrate for Hp $\alpha 1,3$-FucT (Ge et al., 1997; Martin et al., 1997; this study, Table 1, A); and (ii) Martin et al. (1997) found that H type 2 was not the substrate of an $\mathrm{Hp} \alpha 1,3-\mathrm{FucT}$. It should be noted, however, that the fucosyltransferases from different $H$. pylori strains may have different acceptor specificity. Further studies on combined analysis of the $\alpha 1,3-$ and $\alpha 1,2-$ FucTs from various $H$. pylori strains are needed to elucidate whether this novel pathway for the 
synthesis of $\mathrm{Le}^{\mathrm{Y}}$ is general in H. pylori or is strainspecific.

In addition to its function in $\mathrm{Le}^{\mathrm{Y}}$ synthesis, $\mathrm{Hp} \alpha 1$,2FucT is also active on type 1 Lewis structures (summarized in Fig. 4b). This provides a basis for the recent finding that type $1\left(\mathrm{Le}^{\mathrm{c}}\right), \mathrm{H}$ type 1 and $\mathrm{Le}^{\mathrm{a}}$ are expressed in certain $H$. pylori strains $\left(\mathrm{Le}^{\mathrm{b}}\right.$ was also detected in some strains by serological methods but has not yet been confirmed by structural analysis) (Monteiro et al., 1998). Here again, the ability of the $\mathrm{Hp} \alpha 1,2-\mathrm{FucT}$ to synthesize $\mathrm{Le}^{\mathrm{b}}$ from $\mathrm{Le}^{\mathrm{a}}$ indicated that this bacterial enzyme is different from the normal mammalian counterparts, which cannot use $\mathrm{Le}^{\mathrm{a}}$ as substrate. To know if $\mathrm{Le}^{\mathrm{b}}$ can be synthesized from $\mathrm{H}$ type 1 in $H$. pylori awaits the detection of an $\alpha 1,4$-FucT. The $\alpha 1,2$-FucT characterized in this study is from H. pylori strain UA802, which does not produce any type 1 Lewis antigen. This suggests that the same $\alpha 1,2$-FucT enzyme could be used in the strains that produce type 1 epitopes. The failure to produce type 1 Lewis antigens in many $H$. pylori strains could be due to the unavailability of one of the other enzymes involved in the synthesis of Lewis antigens such as galactosyltransferase, which adds $\beta \mathrm{Gal}$ to GlcNAc, or $\alpha 1,3 / 4$-FucT, which places the $\alpha$ Fuc unit at $\beta$ GlcNAc.

Aberrant glycosylation seems to be crucial in human tumour progression (Hakomori, 1989). In addition to that of sialyl Le $e^{\mathrm{a}}$ and sialyl $\mathrm{Le}^{\mathrm{X}}$, the role of $\mathrm{Le}^{\mathrm{b}}$ and $\mathrm{Le}^{\mathrm{Y}}$ as ligands for E-selectin and in adhesion to tumour necrosis factor $\alpha$-activated endothelial cells has also been demonstrated (Kannagi, 1997; Miyake \& Hakamori, 1991; Sakamoto et al., 1986). $\alpha 1,2-$ FucT, the key enzyme regulating the biosynthesis of these structures, has become a marker of tumour progression (Sun et al., 1995). Here, we show that H. pylori $\alpha 1,2$-FucT is functional in the synthesis of both $\mathrm{Le}^{\mathrm{b}}$ and $\mathrm{Le}^{\mathrm{Y}}$, and the synthetic pathways (Fig. 4) are similar to those found in some human cancer cells or tissues (Blaszczyk-Thurin et al., 1988; Yazawa et al., 1993) (Fig. 1b, unusual pathway). We have shown that the expression of the $\alpha 1,2$-FucT-encoding gene in $H$. pylori is regulated at multiple levels including replication, transcription and translation (Wang et al., 1999), and the expression of this gene in H. pylori cells is at a very low level (Table 3). Whether elevated expression of this gene/enzyme in vivo, when $H$. pylori cells are attached to human gastric epithelial cells, is related to $H$. pylori-associated development of human gastric cancer is an important issue which needs to be addressed. To our knowledge, $H$. pylori $\alpha 1,2$-FucT is the first bacterial $\alpha 1,2$-fucosyltransferase that has been characterized. In addition to the biological advantages that $H$. pylori might gain with altered specificity of its $\alpha 1,2$-FucT compared to the counterpart of its host, the novel substrate specificity is of great potential pharmaceutical interest for enzymic synthesis of oligosaccharides.

\section{ACKNOWLEDGEMENTS}

This work was supported in part by funding from the Canadian Bacterial Diseases Network (Centers of Excellence Program) and The National Cancer Institute of Canada with funds from the Terry Fox Run to D.E.T., who is a Medical Scientist with the Alberta Heritage Foundation for Medical Research (AHFMR), and by an Operating Grant to M.M.P. from the Natural Sciences and Engineering Research Council of Canada. G. W. is a holder of a Postdoctoral Fellowship from the Canadian Association of Gastroenterology and Astra Canada in association with an MRC-PMAC award, as well as a fellowship from AHFMR. P.G.B was supported by a Summer Studentship (1998) from AHFMR.

\section{REFERENCES}

Alm, R. A., Ling, L.-S. L., Moir, D. T. \& 20 other authors (1999). Genomic sequence comparison of two unrelated isolates of the human gastric pathogen Helicobacter pylori. Nature 397, 176180.

Appelmelk, B. J., Simoons-Smit, I. M., Negrini, R. \& 17 other authors (1996). Potential role of molecular mimicry between Helicobacter pylori lipopolysaccharide and host Lewis blood group antigens in autoimmunity. Infect Immun 64, 2031-2040.

Appelmelk, B. J., Shiberu, B., Trinks, C. \& 10 other authors (1998). Phase variation in Helicobacter pylori lipopolysaccharide. Infect Immun 66, 70-76.

Aspinall, G. O. \& Monteiro, M. A. (1996). Lipopolysaccharides of Helicobacter pylori strains P466 and MO19: structures of the O antigen and core oligosaccharide regions. Biochemistry $\mathbf{3 5}$, 2498-2504.

Aspinall, G. O., Monteiro, M. A., Pang, H., Walsh, E. J. \& Moran, A. P. (1996). Lipopolysaccharide of Helicobacter pylori type strain NCTC 11637 (ATCC 43504): structure of the O-antigen chain and core oligosaccharide regions. Biochemistry 35, 2489-2497.

Avent, N. D. (1997). Human erythrocyte antigen expression: its molecular bases. Brit J Biomed Sci 54, 16-37.

Blaszczyk-Thurin, M., Sarnesto, A., Thurin, I., Hindsgaul, O. \& Koprowski, H. (1988). Biosynthetic pathways for the Le b and Y glycolipids in the gastric carcinoma cell line KATOIII as analyzed by a novel assay. Biochem Biophys Res Commun 151, 100-108.

Chan, N. W. C., Stangier, K., Sherburne, R., Taylor, D. E., Zhang, Y., Dovichi, N. \& Palcic, M. M. (1995). The biosynthesis of Lewis X in Helicobacter pylori. Glycobiology 5, 683-688.

Ge, Z., Chan, N. W. C., Palcic, M. M. \& Taylor, D. E. (1997). Cloning and heterologous expression of an $\alpha 1,3$ fucosyltransferase gene from the gastric pathogen Helicobacter pylori. J Biol Chem 272, 21357-21363.

Hakomori, S.-I. (1989). Aberrant glycosylation in tumours and tumour-associated carbohydrate antigens. Adv Cancer Res 52, 257-331.

Herry, S., Oriol, R. \& Samuelsson, B. (1995). Lewis histo-blood group system and associated secretory phenotypes. Vox Sang 69, 166-182.

Hitoshi, S., Kusunoki, S., Kanazawa, I. \& Tsuji, S. (1996). Molecular cloning and expression of a third type of rabbit GDP-L-fucose : $\beta$ D-galactoside 2- $\alpha$-L-fucosyltransferase. J Biol Chem 271, 1697516981.

Kannagi, R. (1997). Carbohydrate-mediated cell adhesion involved in hematogenous metastasis of cancer. Glycoconj J 14, 577-584.

Kleene, R. \& Berger, E. G. (1993). The molecular and cell biology of glycosyltransferases. Biochim Biophys Acta 1154, 283-325.

Martin, S. L., Edbrooke, M. R., Hodgman, T. C., van den Eijnden, D. H. \& Bird, M. I. (1997). Lewis X biosynthesis in Helicobacter pylori. Molecular cloning of an $\alpha(1,3)$ fucosyltransferase gene. $J$ Biol Chem 272, 21349-21356. 
Miyake, M. \& Hakamori, S. (1991). A specific cell surface glycoconjugate controlling cell motility: evidence by functional monoclonal antibodies that inhibit cell motility and tumour cell metastasis. Biochemistry 30, 3328-3334.

Monteiro, M. A., Chan, K. H. N., Rasko, D. A. \& 9 other authors (1998). Simultaneous expression of type 1 and type 2 Lewis blood group by Helicobacter pylori lipopolysaccharides. J Biol Chem 273, 11533-11543.

Palcic, M. M., Heerze, L. D., Pierce, M. \& Hindsgaul, O. (1988). The use of hydrophobic synthetic glycosides as acceptors in glycosyltransferase assays. Glycoconj J 5, 49-63.

Sakamoto, J., Furukawa, K., Cordon-Carlo, C., Yin, B. W. T., Rettig, W. J., Oettgen, H. F., Old, L. J. \& Lloyd, K. O. (1986). Expression of Lewis a, Lewis b, X, and Y blood group antigens in human colonic tumours and normal tissue and in human tumourderived cell lines. Cancer Res 46, 1553-1561.

Sambrook, J., Fritsch, E. F. \& Maniatis, T. (1989). Molecular Cloning: a Laboratory Manual, 2nd edn. Cold Spring Harbor, NY : Cold Spring Harbor Laboratory.

Sarnesto, A., Kohlin, T., Thurin, J. \& Blaszczyk-Thurin, M. (1990). Purification of $\mathrm{H}$ gene-encoded $\beta$-galactoside $\alpha 1-2$ fucosyltransferase from human serum. J Biol Chem 265, 15067-15075.

Sarnesto, A., Kohlin, T., Hindsgaul, O., Thurin, J. \& BlaszczykThurin, M. (1992). Purification of the secretor-type $\beta$-galactoside $\alpha 1$-2-fucosyltransferase from human serum. J Biol Chem 267, 2737-2744.

Sherburne, R. \& Taylor, D. E. (1995). Helicobacter pylori expresses a complex surface carbohydrate, Lewis X. Infect Immun 63, 4564-4568.

Sun, J., Thurin, J., Cooper, H. S., Wang, P., Mackiewicz, M., Steplewski, Z. \& Blaszczyk-Thurin, M. (1995). Elevated expression of $\mathrm{H}$ type GDP-L-fucose: beta-D-galactoside alpha-2-L-fucosyltransferase is associated with human colon adenocarcinoma progression. Proc Natl Acad Sci USA 92, 5724-5728.

Tabor, S. \& Richardson, C. C. (1985). A bacteriophage T7 RNA polymerase/promoter system for controlled exclusive expression of specific genes. Proc Natl Acad Sci USA 82, 1074-1078.
Taylor, D. E., Rasko, D. A., Sherburne, R., Ho, C. \& Jewell, L. D. (1998). Lack of correlation between Lewis antigen expression by Helicobacter pylori and gastric epithelial cells in infected patients. Gastroenterology 115, 1113-1122.

Tomb, J.-F., White, O., Kerlavage, A. R. \& 39 other authors. (1997). The complete genome sequence of the gastric pathogen Helicobacter pylori. Nature 388, 539-547.

Wang, G., Rasko, D. A., Sherburne, R. \& Taylor, D. E. (1999). Molecular genetic basis for the variable expression of Lewis $\mathrm{Y}$ antigen in Helicobacter pylori: Analysis of the $\alpha(1,2)$ fucosyltransferase gene. Mol Microbiol 31, 1265-1274.

Watkins, W. M. (1995). Biosynthesis. Molecular basis of antigenic specificity in the $\mathrm{ABO}, \mathrm{H}$, and Lewis blood group systems. In Glycoproteins, pp. 313-390. Edited by J. Montreuil, H. Schachter \& J. F. G. Vliegenthart. Amsterdam: Elsevier.

Wirth, H.-P., Yang, M., Karita, M. \& Blaser, M. J. (1996). Expression of the human cell surface glycoconjugates Lewis $\mathrm{X}$ and Lewis $\mathrm{Y}$ by Helicobacter pylori isolates is related to cagA status. Infect Immun 64, 4598-4605.

Wirth, H.-P., Yang, M., Peek, R. M., Tham, K. T. \& Blaser, M. J. (1997). Helicobacter pylori Lewis expression is related to the host Lewis phenotype. Gastroenterology 113, 1091-1098.

Wirth, H.-P., Yang, M., Peek, R. M., Hook-Nikanne, J., Fried, M. \& Blaser, M. J. (1999). Phenotypic diversity in Lewis expression of Helicobacter pylori isolates from the same host. J Lab Clin Med 133, 488-500.

Yao, Z., Liu, H. \& Valvano, M. A. (1992). Acetylation of O-specific lipopolysaccharides from Shigella flexneri $3 \mathrm{a}$ and $2 \mathrm{a}$ occurs in Escherichia coli $\mathrm{K}-12$ carrying cloned S. flexneri $3 \mathrm{a}$ and $2 \mathrm{a} r \mathrm{fb}$ genes. J Bacteriol 174, 7500-7508.

Yazawa, S., Nakamura, J., Asao, T., Nagamachi, Y., Sagi, M., Matta, K. L., Tachikawa, T. \& Akamatsu, M. (1993). Aberrant $\alpha 1,2$ fucosyltransferases found in human colorectal carcinoma involved in the accumulation of Le b and $\mathrm{Y}$ antigens in colorectal tumours. Jpn J Cancer Res 84, 989-995.

Received 8 April 1999; revised 12 July 1999; accepted 22 July 1999. 